\title{
Socio-economic status of human-elephant conflict: Its assessment and solutions
}

\author{
A. K. Thakur, D. K. Yadav and M. K. Jhariya* \\ Department of Farm Forestry, Sarguja University, Ambikapur-497001 (C.G.), INDIA \\ *Corresponding author. E-mail: manu9589@gmail.com
}

Received: February 22, 2016; Revised received: August 25, 2016; Accepted: November 14, 2016

\begin{abstract}
The study was made to examine the effect of human-elephant conflict (HEC) on socio-economic vulnerability in corridors of northern Chhattisgarh. Incidents relating to conflicts were observed and analyzed to understand the socio-economic status of the people, their attitudes towards elephant, the way people and elephants were affected along with different aspects of conflicts. The records whatsoever available on HEC of forest department were also took into consideration during analysis. It was found that majority of respondents involved in farming besides other sources like livestock (63.0\%), NTFPs collection (42.50\%) etc. Paddy $(57.50 \%)$ and sugarcane $(40.0 \%)$ constitute major crops which likely favours the incidence of HEC in the region. Nearly 112 houses and 939.02 acre of crops were damaged along with 06 human deaths. It was found that $46 \%$ of the respondents respected the animal as a religious figure while $30 \%$ fear them and most of the respondents $(77.50 \%)$ were in favour of compensation. This necessitated a detailed assessment of habitat suitability and dispersal corridor for elephants in the area. Therefore, an attempt has been made to present various aspects of HEC along with management implications.
\end{abstract}

Keywords: Conflicts, Corridor, Crop damage, Habitat, HEC

\section{INTRODUCTION}

Human-elephant conflict (HEC) is a key concern and emerged now as a major issue both in terms of conservation and socioeconomic significance (Sukumar, 1994; Easa, 2002; Singh et al., 2002; Kushwaha and Hazarika, 2004; Thakur et al., 2015; Borah and Bhuyan, 2016). Elephants are mega-herbivores and commonly raid crops, causing economic losses, death and injury to people. Elephants were known to coexist with humans for centuries but then there were fewer humans and more land and therefore, more carrying capacity of habitats for elephants. Conflicts were known to be present in the past also due to agricultural damage and crop invasion (Wisumperuma, 2003).

HEC is a symptom of inappropriate land use practices such as permanent human settlements and growing irrigated food crops adjacent to elephant range lands (Hoare, 2001; Treves et al., 2006; IUCN, 2006; Fernando et al., 2008; Gubbi, 2012). Loss or fragmentation of habitat and blocked traditional routes restrict elephants' access to forage, water etc. It is reported that they compensate for this loss by eating crops and stored grain (Sukumar, 1989). Elephants are increasingly caught in the pincer grip of habitat loss/ fragmentation and retaliation caused by increasing conflict. Diversion of forests into agriculture, fragmentation, settlements, shrinkage and degradation resulting in increased HEC (Sukumar, 1994; Singh et al., 2002; Singh, 2002). Elephants, in search of food and water tend to enter into human habitations and in the process, often come into direct conflicts (Sukumar, 1994; Kush- waha and Hazarika, 2004). Corridors are narrow strips of forests connecting two larger forest areas and thereby facilitating movement and dispersal of animals between these patches (Beier and Noss, 1998). Preservation and restoration of corridors are an important aspect of reducing the negative effects of habitat fragmentation (Khanna et al., 2001; Venkataraman, 2002; Nandy et al., 2007; Thakur et al., 2015).

Asian elephants were found in northern Chhattisgarh (central India) since historical times, however, in the early part of the $20^{\text {th }}$ century they became locally extinct. Since then, incidents of HEC have been increasing and became alarming in the corridors due to straying of migratory elephants (Singh, 2002). Long stay of elephants in this corridor may due to better forest cover $(44 \%)$, and migration of elephants from Jharkhand and Orissa (Singh, 2002; Earth Matters Foundation, 2008; Thakur et al., 2015). The Sarguja division is primarily inhabited by tribal communities which are dependent largely on agriculture and forest produces. So, any incidence related to HEC has direct impact on socioeconomic status and livelihood of the people and posing challenges for conservation. Therefore, the present study was undertaken to assess the scenario of HEC, their assessment and possible solution to reduce the conflict between human being and wildlife along with conservation and management perspectives.

\section{MATERIALS AND METHODS}

The study on socio-economic status of HEC, their assessment and solutions of northern Chhattisgarh was 
carried out at four blocks viz., Lundra, Batouli, Sitapur in Sarguja district and Farsabahar in Jashpur district, respectively. The study area lies between $23^{\circ} 37^{\prime} 25^{\prime \prime}$ to $24^{\circ} 6^{\prime} 17^{\prime \prime}$ north latitude and $81^{\circ} 31^{\prime} 40^{\prime \prime}$ to $84^{\circ} 4^{\prime} 40^{\prime \prime}$ east longitude. Sarguja forest division bounds to the Badalkhol, Semrasot, Tamorpingla sanctuary and Guru Ghasidas national park which support a substantial number of wild elephants. Neighboring villages of the corridors are oftenly visited by the elephants during the year and causes subsequent loss of crops, property and life. The climate of the region reflects hot summer and well distributed rainfall during the monsoon season. The chief feature of climate is long dry period; average monthly temperature rising over $18^{\circ} \mathrm{C}$, through maximum summer temperature may even go up to $46^{\circ} \mathrm{C}$ (Sinha et al., 2014 \& 2015; Yadav et al., 2015; Jhariya and Yadav, 2016). The flora of these areas are changing frequently with the human interferences and landuse. Physiographically, they are remarkable land-forms and average height of area varies from 600 meter and more.

The field study was conducted in forest fringe areas where migrated elephants were encountered. Incidents relating to conflicts such as crop and house damage, human death and injury, elephant death, cause of all such conflicts were observed. After preliminary survey of the HEC affected areas collection of information from the respondents were taken by informal interviews, questionnaire method, participatory rural appraisal and personal observations (Chambers, 1994). Local people of the affected villages/forest areas including victims of conflict were interviewed to understand their socioeconomic status, their attitudes towards elephant, the way people and elephants were affected and different aspects of conflicts. The records whatsoever available on HEC of forest department were also took into consideration during analysis. Data collected on various aspects of HEC from different blocks were compiled and analyzed after getting opinion and expression of the respondents.

\section{RESULTS AND DISCUSSION}

Socio-economic profile: Sarguja district of Chhattisgarh is mainly inhabited by different tribal communities whose main occupation is agriculture and collection of forest products. Out of the 40 households interviewed 33 respondents were male while 07 were female. The survey targeted to interview the head of the household as they were more informative and reliable source for data. In their absence other members of the households were interviewed. Majority of the respondents $(47.50 \%)$ belonged to young age group (up to 35 years), followed by $37.5 \%$ middle age group (36 to 55 years), whereas $15.0 \%$ respondents belongs to old age group (more than 55 years). The family size in the study sites comprised $60.0 \%$ small family size (up to 5 members) and $40.0 \%$ large family size (above 5 members). During the field study it was found that about $41.0 \%$ of respondents had primary to middle school education, followed by $23.0 \%$ which had high school education, $18.0 \%$ had gained higher secondary and above education, while $18.0 \%$ were found to be illiterate.

Source of income: During the study it was found that the main source of income was farming. Besides farming people also generate income from other enterprises like livestock rearing $(63.0 \%)$, NTFPs collection $(42.50 \%)$, employed $(2.50 \%)$, business $(22.50 \%)$ as well as wage labors to neighbors fields (Table 1). Agriculture and livestock rearing is not practiced commercially but only for household consumption. Therefore, any damage caused by elephant raid had direct consequence on the livelihood of the people.

Major crops grown: Paddy and sugarcane are the major crops grown in study site which constitutes $57.50 \%$ and $40.0 \%$, respectively while the other crops grown are maize, wheat, sesame, black gram etc (Table 2).

Land holding and land use pattern: It was found that $37.50 \%$ respondents have more than 10 acre of land. While $32.50 \%$ respondents have 5-10 acre net cultivated area and $35.0 \%$ have less than 5 acre uncultivated land (table 3).

Source of irrigation: Majority of the people depends upon rain $(57.50 \%)$ as a source of irrigation, while the other sources are shown in table 4.

Farm assets: Majority of people have their own land $(82.50 \%)$ and other farm assets are shown in (table 5).

House and crop damage: The information collected from HEC region revealed that nearly 112 houses and total 939.02 acre of crops were damaged by elephant in different seasons during the study period (2014-2015).

Human death: A total of 06 human death occurred as a result of HEC during the year 2012-2015 recorded by Forest Department of Sarguja. During the study period 3 human deaths and 12 human injuries were observed. An analysis of intensity of conflict over a period of 04 years, showed that the maximum number of human death was occurred in 2014-2015.

Elephant (Elephas maximus) death: There is dearth of information from forest department regarding elephant deaths. Secondary data collected and compiled from the local newspaper reveals that 02 adult elephants and 02 calves were found dead during the study period.

Attitude and perceptions of the people towards the elephant: The elephant is highly respected and worshiped among the people as it is a culturally important species and having a religious status among the people. Respondents were asked to choose between Like, Fear, Hate and Respect in order to see their attitude towards the elephant. It was found that $46 \%$ of the respondents respect the animal as a religious figure and pray although at the same time $30 \%$ fear the animal. Although, most of the respondents have referred to the animal as a religious figure but at the same time they also 
A. K. Thakur et al. / J. Appl. \& Nat. Sci. 8 (4): 2104-2110 (2016)

Table 1. Distribution of respondents according to their source of income in Sarguja.

\begin{tabular}{lc}
\hline Source of income & Contribution (in \%) \\
\hline Agriculture & 100.00 \\
Livestock & 62.50 \\
NTFP collection & 42.50 \\
Business & 22.50 \\
Hunting & 12.50 \\
Employed & 2.50 \\
\hline
\end{tabular}

Table 3. Land holding and land use pattern in Sarguja area.

\begin{tabular}{ll}
\hline Land - Total area (Acre) & $\mathbf{( \% )}$ \\
\hline $0-5$ & 42.50 \\
$5-10$ & 20.00 \\
$<10$ & 37.50 \\
\hline Net cultivated & \\
\hline $0-5$ & 45.00 \\
$5-10$ & 32.50 \\
$<10$ & 22.50 \\
\hline Uncultivated & \\
\hline $0-5$ & 35.00 \\
$5-10$ & 20.00 \\
$<10$ & 2.50 \\
\hline Fallow land & \\
\hline $0-5$ & 7.50 \\
$5-10$ & 10.00 \\
$<10$ & 0.00 \\
\hline Irrigated area & \\
\hline $0-5$ & 17.50 \\
$5-10$ & 10.00 \\
$<10$ & 0.00 \\
\hline
\end{tabular}

Table 5. Farm assets of respondents in the Sarguja area.

\begin{tabular}{ll}
\hline Farm assets & $\mathbf{( \% )}$ \\
\hline Katcha house & 92.50 \\
Land & 82.50 \\
Cattle shed & 60.00 \\
Well & 47.50 \\
Plough & 45.00 \\
Animals & 41.50 \\
Cows & 35.00 \\
Tube well & 27.50 \\
Buffaloes & 22.50 \\
Pakka house & 12.50 \\
Electronic motor & 9.50 \\
Farm shed & 7.50 \\
\hline
\end{tabular}

Table 2. Major crops grown in the Sarguja area.

\begin{tabular}{lc}
\hline Major crop grown & $\mathbf{( ~ \% )}$ \\
\hline Paddy & 57.50 \\
Sugar cane & 40.00 \\
Maize & 32.50 \\
Sesame & 27.50 \\
Black gram & 10.00 \\
Wheat & 7.50 \\
\hline
\end{tabular}

Table 4. Source of irrigation in Sarguja area.

\begin{tabular}{ll}
\hline Source of irrigation & $\mathbf{( \% )}$ \\
\hline No available (Rain fed) & 57.50 \\
Well & 22.50 \\
Others & 12.50 \\
Tube well & 12.50 \\
River & 10.00 \\
\hline
\end{tabular}

seemed a bit frustrated with the problems of HEC.

Compensation: The study included few aspects to know how the people felt about compensation that experience loss directly. Most of the respondents (77.5\%) felt that compensation was necessary for those who had experienced crop and property damages. However, $22.5 \%$ of the respondents felt that compensation should be awarded only in cases of severe damage. The compensation provided by the forest department of Sarguja on different incidents viz., house, animal, crop damage etc., is presented in table 6 .

In the study it was found that $60 \%$ household belonged to joint family while $40 \%$ were nuclear family (on the basis of members of family). Majority of respondents $(42.50 \%)$ had small size of land holding. The division of land from one generation to another generation resulted in nuclear structure of families in the community and marginal and small size of land holding (Pal, 2009). The main source of occupation is farming in the study area. Similarly, Geetha and Devi (2008) in the line of agreement with the present study reported that agriculture being the prevailing main occupation and back bone of the economy in the area, most of the households. Similarly, farming and allied activities being major source of livelihood of the households, the

Table 6. Compensation provided by Sarguja forest department for different incidents during the year 2012-2016 (Source: District Forest Department, Ambikapur, Sarguja).

\begin{tabular}{lllll}
\hline \multirow{2}{*}{ Year } & \multicolumn{3}{c}{ Compensation amount (Rs.) and Number of incident } \\
\cline { 2 - 5 } & Human damage & Animal damage & Crop damage & House and other \\
\hline $2012-13$ & 0.00 & $29000.00(3)$ & $4409687.00(1225)$ & $930480.00(359)$ \\
$2013-14$ & $200000.00(1)$ & 0.00 & $5989939.00(909)$ & $523368.00(104)$ \\
$2014-15$ & $300000.00(1)$ & $15000.00(1)$ & $4865345.00(1563)$ & $930404.00(121)$ \\
$2015-16$ & $1600000.00(4)$ & $15000.00(1)$ & $3627346.00(895)$ & $1701230.00(325)$ \\
\hline
\end{tabular}

Values in parenthesis are compensation amount (in rupees) and the number of related incidents (Shown in brackets) in the study area. 
possession of minimal farm implements is indispensable (Chaudhary and Panjabi, 2005). The families engaged in wage labour, business, service, caste occupation and other activities as their main occupation were also doing agriculture as their subsidiary occupation (Pal, 2009). Livestock rearing (62.50\%) ranks second occupation after farming in the study area. Holding good number of livestock could be attributed to the fact that livestock rearing was the most preferred secondary occupation (Pal, 2009). Livestock support agriculture and allied activities besides providing nutritional, social, economic, religious and recreational benefits to the people (Bijalwan et al., 2012). The families engaged in wage labour, business, service, caste occupation and other activities as their main occupation were also doing agriculture as their subsidiary occupation (Pal, 2009). Low agricultural production due to lack of irrigation facilities, scientific know -how, improved equipments and machinery, mono-cropping system, low fertility of land and erratic climatic condition accrue paltry income to the farmers (Krishnamoorthy et al., 2003). Similarly, majority of the wage labourers are unskilled, they are not getting consistent income due to irregular employment and underpayment (Kumar et al., 2010). The low housing status $(92.50 \%$ katcha house) in the study area could be attributed to low socioeconomic condition, poverty, lack of infrastructure, rural environment etc. (Lakra and Cardenas, 2002).

Degradation of forest areas due to increasing human pressure tend towards HEC. When the interactions between elephants and human beings become very close certainly there would be a conflict between man and elephant. Elephants cause crop damage and attacks people which lead to severe injuries and ultimately to death. Besides this elephants also damage to human properties. Crop (939.02 acres) and house (112 Nos.) damage by elephants was reported to be main consequence of HEC in the study site. Fernando and Pastorini (2011) found that the HEC as the main threat to Asian elephants and describe crop raiding as the primary reason for HEC. Therefore, many workers identified Asian elephant as a serious agricultural pest (Bandara and Tisdell, 2002; Jarungrattanapong and Sajjanand, 2011; Sarker and Roskaft, 2012).

The crop raiding mainly in case of rice and sugarcane, which is generally liked by the elephants in this region, starts right from initial growth to its final harvesting. However, the intensity and frequency of crop raiding attains peak level as the crops comes under maturation stage. The HEC was found to be higher during the riping of paddy which is in line agreement with previous reports (Bal et al., 2011; Gubbi, 2012). However, the incidence of crop raiding was not uniformaly distributed, as few villages suffering significantly more damage (especially forest fringes) than the others which revealed the distance from corridors or elephant habitat increases the conflict gradually decreases.

Household and property damage by wild elephants is major aspect of HEC after crop raiding. The main cause behind majority of the house damage cases was for stored paddy and other feeding materials. Likewise, house damage and human injury are due to the habitation in forest fringe areas and availability of palatable tree species nearby their homestead, farm lands etc. and the tribals of this region store the rice, wheat and local made liqueur (mahua wine/daru, Mudh, Kosna/ Usna, rice bear, tadi, sulfi, hadiya etc.) in house which attracts the elephant as a result of which severe incidences takes place (Thakur et al., 2015). Similar findings were also reported by Sarker and Roskaft, 2011; Sukumar, 2006). Damage to households and property occurred more or less throughout the year with a peak in cropping season especially in rainy and winter season (Sarkar and Roskaft, 2010).

Human injury and death due to HEC is one of the very crucial aspects conflicts. Although the number of human injury and death incidence by elephants in northern corridors is comparatively less. In the present investigation the death of elephant was low. Likewise IUCN (2004) showed that seven elephants dead in south-eastern of Bangladesh during 2000-2001. It was found in the present investigation that most of the respondents respected the animal as a religious figure. The general reverence towards plants and animals in some Indian religions has often been reported to be the main reason for a positive attitude towards elephant, wildlife and nature reserves (Gurung and Lahiri Choudhury, 2000 and 2001).

Cost of human-wildlife conflicts is of three types: direct, indirect and opportunity costs (Thirgood et al., 2005; Hoare, 2001). Direct cost which is of serious concern is imposed by crop, property and life damages and investment on capital and raw materials. Subsistence farmers may require direct compensation for survival but the amount compensated should not be the full amount lost, as this may encourage complacency. This can be expressed as annual income loss as a result of HEC (Naughton et al., 1999). In order to impose economic losses by HEC government provides monetary compensations to the victims. Compensation is generally a non-preventive mitigation measure that does not reduce the HEC (Hoare, 2001). Now there is a steep increase in claims by farmers depicting either an increase in conflict or increased awareness to claim compensation (Gubbi, 2012). In contrary to this Bal et al. (2011) noted that it could be an underestimate due to farmers not claiming compensation. The compensation paid in the study area was very low for the losses undergone by farmers. Meagre payments have been an important factor in creating animosity amongst farmers against wildlife. Nevertheless, this scheme has come under severe criticism as compensation payments are 
often too meagre, delayed and the procedures to avail of these compensations are time-consuming.

Conservation and management: The Asian elephant (Elephas maximus) is listed as an endangered species under Schedule-I of Indian Wildlife Protection Act (1972), which enables high protection priority under Indian law. No single solution is effective and different approaches need to be integrated to address HEC proactively. Lack of a robust policy also leads to an inordinate focus on the symptoms rather than the causes of the problem. With the increase in population and land use changes resulting in further conversion of elephant habitat into agricultural land, there would not be an end to the problem of HEC. The encroachment of its natural habitat and conversion to settlement is of primary concern which results in conflict. A participatory approach on the basis of the forest's need and existing pattern is essential which needs to be adapted to check the problem of HEC. Establishing good communication network along with awareness programmes involving local people, forest dwellers and forest department (Thakur et al., 2015).

According to IUCN (2006), the current approach dealing with conflict has largely been adhoc, and predisposed to failure because of inappropriate application of methods, lack of involvement of local people, lack of monitoring of conflict and conflict mitigation measures and inadequate understanding of elephant ecology. Some suggestions are forwarded to mitigate the problem of HEC in the study region which includes: facilitate food and shelter to the elephants, proper emphasis should be given to develop a more variable and feasible dense forest cover, open up the elephant corridors for free movement of elephants, alternatives should be given to the livelihood of the affected villages, proper zonation of corridors can be created, incorporation of unpalatable crops like chilly, citrus and tobacco, etc in cropping systems along with live fencing, emphasis should be given to develop permanent drinking water facility across the corridors, local people along with forest officials should be imparted proper training by the experts, so that they can drive away the elephants using proper scientific methods. In northern parts of Chhattisgarh, elephant corridors are being blocked due to the excessive pressure from deforestation, elicit felling, poaching, land use change, fragmentation, infrastructure development, expanding farming activities as well as illegal encroachment by local people. A viewpoint from both sides indicates that the human being is the key indicator for such a conflict rather than the elephant. There is a need for a clear policy and strategic planning to resolve elephant-human conflict and elephant conservation. Sarguja forest department is taking several initiatives which include awareness among the local people, Haathi Sahayata Kendras, workshops, seminars, trainings, compensations etc. (Thakur et al., 2015).

\section{Conclusion}

HEC in the study region have not been so intensive as compared to other parts of country. Crop raiding is arguably one of the defining challenges in HEC. From the findings it is quite clear that HEC in the region is an outcome of the biotic interference. The land-use change and shrinkage of corridors are a product of the diminishing area of elephant habitat and shortage of food and water in the area which favour the more incidence of crop raid. Conflicts happen directly when elephants damage crops, infrastructure/properties or attack people and cause injuries or even death. Hence, such incidence affects socio-economic development of the residing people. Addressing the root causes of such conflict is a basic first step towards HEC mitigation. Effective management of corridors would go a long way in ensuring symbiotic relationship between elephants and human being. Therefore, present findings will be useful for the government and non-government bodies for the improvement of the corridors, their conservation, management and livelihood of the tribal.

\section{ACKNOWLEDGEMENTS}

The authors thanks the Sarguja forest department particularly Mr. Mohammad Sahid, DFO, Sarguja for valuable guidance and also to the people of the study areas for sharing the valuable information.

\section{REFERENCES}

Bal, P., Nath, C.D., Nanaya, K.M., Kushalappa, C.G. and Garcia, C. (2011). Elephants also like coffee: trends and drivers of human-elephant conflicts in coffee agroforestry landscapes of Kodagu, Western Ghats, India. Environ. Manage., 47: 789-801

Bandara, R. and Tisdell, C. (2002). Asain elephants as agricultural pests: Damages, economics of control and compensation in Sri Lnaka. Natural Resources Journal, 42: 491-519

Beier, P. and Noss, R.F. (1998). Do habitat corridors provide connectivity?. Conservation Biology, 12: 1241-1252

Bijalwan, A., Sharma, C.M. and Kediyal, V.K. (2012). Socioeconomic status and livelihood support through traditional agroforestry systems in hill and mountain agroecosystem of Garhwal Himalaya, India. The Indian Forester, 138(12): 1423-1430

Borah, R.K. and Bhuyan N. (2016). A comprehensive study of human-elephant conflict in the bordering areas of the three reserve forests of Lakhimpur district, Assam. International Journal of Interdisciplinary Research in Science Society and Culture, 2(1): 132-143

Chaudhary, M.C. and Panjabi, N.K. (2005). Adoption behaviour of tribal and non-tribal farmers regarding improved Social Forestry Practices. Rural India, 67(6): 140-141

Chambers, R. (1994). The origins and practice of participatory rural appraisal. World Development, 22(7): 953-969

Earth Matters Foundation (2008). A Home for Elephants, People and Tribal Communities: Managing Human Elephant Conflict in Chhattisgarh. Detailed Project Report. Earth Matters Foundation, New Delhi. 
Easa, P.S. (2002). Asian elephants in India: A review. pp. 1422. In: V. Menon, S. K. Tiwari, P. S. Easa \& R. Sukumar (eds.) Right of Passage: Elephant Corridors of India. Conservation Reference Series No. 3. Wildlife Trust of India, New Delhi

Fernando, P. and Pastorini, J. (2011). Range-wide status of Asian elephants. Gajah, 35: 15-20

Fernando, P., Kumar, M.A., Williams, A.C., Wickramanayake, Aziz, E.T. and Singh, S.M. (2008). Review of human-elephant conflict mitigation measures practiced in South Asia. WWF-World Wide Fund for Nature, AREAS Technical Support Document submitted to World Bank.

Geetha, G.S. and Devi, R.G. (2008). Technology adoption and training needs of sericulture farmers - a case study in NGO. Indian Journal Agriculture Science, 42(3): 157 $-163$

Gubbi, S. (2012). Patterns and correlates of human-elephant conflict around a south Indian reserve. Biological Conservation, Doi:10.1016/j.biocon.2012.01.046.

Gurung, S. and Lahiri Choudhury, D.K. (2000). Project Elephant-human conflict in Asia state report on Meghalaya, India. Part-I. Asian Elephant Research and Conservation Centre.

Gurung, S. and Lahiri Choudhury, D.K. (2001). Project: Elephant-human conflict in Asia state report on Meghalaya, India,. Community development-block reports. Part-II. Asian Elephant Research and Conservation Centre.

Hoare, R.E. (2001). A decision support system for managing human-elephant conflict situations in Africa.

IUCN (2006). Asian Elephant Range Status Meeting, 24-26 January 2006, Kuala Lumpur, Malaysia: Report. Switzerland.

IUCN (2004). Assessment of elephant habitat and local capacity and awareness enhancement programme at Chunati Wildlife Sanctuary. Conservation of Asian elephants in Bangladesh IUCN- The World Conservation Union, Bangladesh, Country office, Dhaka, Technical Report.

Jhariya, M.K. and Yadav, D.K. (2016). Understorey Vegetation in Natural and Plantation Forest Ecosystem of Sarguja (C.G.), India. Journal of Applied and Natural Science, 8(2): 668-673

Jarungrattanapong, R. and Sajjanand, S. (2011). Analysis of policy options to convert human-elephant conflict into human-elephant harmony. Research Report No. 2011RR14. Economy and Environment Program for Southeast Asia.

Khanna,V., Ravichandran, M.S. and Kushwaha, S.P.S. (2001). Corridor analysis in Rajaji-Corbett Elephant Reserve: A Remote sensing and GIS approach. Journal of the Indian Society of Remote Sensing, 29: 41- 46

Krishnamoorthy, L., Vardharaj, S., Mani, G. and Vinila, J.E.A. (2003). Collection and marketing of non-timber forest products in Tamil Nadu. Journal of Non-Timber Forest Products, 10(1/2): 76-82

Kumar, P., Rawat, L. and Basera, H. (2010). Socioeconomic studies of Henwal Watershed, Tehri Garhwal, Uttarakhand. Indian Journal Forestry, 33(2): 149- 154

Kushwaha, S.P.S. and Hazarika, R. (2004). Assessment of habitat loss in Kameng and Sonitpur Elephant reserves. Current Science, 87: 1447-1453
Lakra, V. and Cardenas, V.R. (2002). Socioeconomic and demographic profile of the farmers in the tribal areas of south Bihar. Bharatiya Samajik Chintan, 25(1-2): 80-84

Nandy, S., Kushwaha, S.P.S. and Mukhopadhyay, S. (2007). Monitoring the Chilla-Motichur wildlife corridor using geospatial tools. Journal for Nature Conservation, 15: 237-244

Naughton, L., Rose, R. and Treves, A. (1999). The social dimensions of human-elephant conflict in Africa: A literature review and case studies from Uganda and Cameroon. A report to the African Elephant Specialist, Human-elephant Task, Conflict Task Force Groups of IUCN, Glands, Switzerland.

Pal, G. (2009). Resource use efficiency and level of technology adoption in lac cultivation among trained and untrained lac growers in Jharkhand. International Journal Agricultaral Science, 592: 615-618

Sarker, A.H.M. and Roskaft, E. (2012). Farmer characteristics and their perception of Asian elephants (Elephas maximus) as an agricultural pest in Bangladesh. International Journal of Biodiversity and Conservation, 4 (14): 560-572

Sarker, A.H.M.R. and Roskaft, E. (2010). Human attitudes towards conservation of Asian elephants (Elephas maximus) in Bangladesh. International Journal of Biodiversity and Conservation, 2(10): 316-327

Sarker, A.H.M.R. and Roskaft, E. (2011). Human attitudes towards the conservation of protected areas: a case study from four protected areas in Bangladesh. Oryx, 45 (3): $391-400$

Singh, A.K., Singh, R.R. and Chowdhury, S. (2002). HumanElephant conflicts in changed landscapes of south West Bengal, India. Indian Forester, 128: 1119-1132

Singh, R.K. (2002). Elephants in exile: A rapid assessment of the Human-Elephant conflict in Chhattisgarh. An Occasional Report of a Rapid Action Project as part of the Elephant Conservation Project. Occasional Report No. 5, Wildlife Trust of India, New Delhi.

Sinha, R., Jhariya, M.K. and Yadav, D.K. (2015). Assessment of sal seedlings and herbaceous flora in the khairbar plantation of Sarguja Forest Division, Chhattisgarh. Current World Environment, 10(1): 330-337

Sinha, R., Yadav, D.K. and Jhariya, M.K. (2014). Growth performance of Sal in Mahamaya central forest nursery (Ambikapur), Chhattisgarh. International Journal of Scientific Research, 3(11): 246-248

Sukumar, R. (1989). The Asian Elephant: ecology and management. Oxford University Press, Cambridge, UK.

Sukumar, R. (1994). Wildlife-human conflict in India: An ecological and social perspective. pp. 303-317. In: R. Guha (ed.) Social Ecology. Oxford University Press, New Delhi.

Sukumar, R. (2006). A brief review of the status, distribution and biology of wild Asian elephants. International Zoological Year Book, 40: 1-8.

Thakur, A.K., Yadav, D.K. and Jhariya, M.K. (2015). Human-Elephant Conflict Scenario in Corridors of Northern Chhattisgarh. Journal of Plant Development Sciences, 7(11): 821-825

Thirgood, S., Woodroffe, R. and Rabinowitz, A. (2005). The impact of human-wildlife conflict on human lives and livelihoods in Woodroffe, R., Thirgood, S., \& Rabinowitz, A. (eds). People and Wildlife: Conflict or co- 
A. K. Thakur et al. / J. Appl. \& Nat. Sci. 8 (4): 2104-2110 (2016)

existence. Cambridge University Press. The Edinburgh Building, Cambridge CB2 2RU, UK. pp. 13-26

Treves, A., Wallace, R.B., Naughton-Treves, L. and Morales, A. (2006). Co-managing human wildlife conflicts: a review. Human Dimensions of Wildlife, 11: 383-396

Venkataraman, A. (2002). What is an Asian elephant (Elephas maximus) corridor? pp. 24-31. In: V. Menon, S.K. Tiwari, P.S. Easa \& R. Sukumar (eds.) Right of Passage: Elephant Corridors of India. Conservation Reference Series No. 3, Wildlife Trust of India, New Delhi.

Wisumperuma, D. (2003). Human-elephant relationships in Sri Lanka: A historical and archaeological perspective. In Symposium for Human elephant relationships and conflicts, Jayawardene, J. (Ed.). Biodiversity and Elephant Conservation Trust, Colombo.

Yadav, D.K., Jhariya, M.K., Kumar, A. and Sinha, R. (2015). Documentation and Ethnobotanical importance of Medicinal Plants found in Sarguja district. Journal of Plant Development Sciences, 7(5): 439-446

$\mathrm{Yu}, \quad$ S.J. and Nguyen, S.N. (1992). Detection and biochemical characterization of insecticide resistance in the diamondback moth. Pesticide Biochemistry \& Physiology, 44:74-81

Zhao, J.Z. Li, Y.X. Collins, H.L. Gusukuma-Minuto, L. Mau, R.F.L. Thompson, G.D. and Shelton, A.M. (2002). Monitoring and characterization of diamondback moth (Lepidoptera: Plutellidae) resistance to spinosad. Journal of Economic Entomology, 95: 430-436 